\title{
BMJ
}

\section{Choice of fluids for resuscitation in children with severe infection and shock: systematic review}

\author{
Samuel Akech, clinical research fellow, ${ }^{1}$ Hannah Ledermann, paediatric clinical trainee, ${ }^{1}$ Kathryn Maitland, \\ professor of tropical paediatric infectious disease ${ }^{1,2}$
}

${ }^{1}$ Centre for Geographic Medicine Research (Coast), Kenya Medical Research Institute-Wellcome Trust Programme, PO Box 230, Kilifi, Kenya

${ }^{2}$ Department of Paediatrics and Wellcome Trust Centre for Clinical Tropical Medicine, Faculty of Medicine, Imperial College,

London W2 1PG

Correspondence to: $K$ Maitland, KEMRIWellcomeTrustProgramme, PO Box 230, Kilifi, Kenya kmaitland@kilifi.kemri-wellcome. org

Cite this as: BMJ 2010:341:C4416 doi:10.1136/bmi.c4416

\section{ABSTRACT}

Objective To systemically review the evidence from clinical trials comparing the use of crystalloids and colloids for fluid resuscitation in children with severe infection.

Data sources Medline (1950-2008), PubMed, the Cochrane Library, Embase (1980-2008), and reference lists.

Eligibility criteria Published studies comparing fluid resuscitation with crystalloid or colloidal solutions in severe infectious illness in children aged $>1$ month to $\leq$ 12 years. Controlled trials and randomised controlled trials were separately selected by two unblinded investigators who also independently extracted data. Main outcome measures Efficacy in the treatment of shock, mortality, and reported adverse events. Results Nine trials fulfilled criteria, eight of which compared crystalloids with colloids. All trials were conducted in settings with poor resources and predominantly included patients with malaria or dengue haemorrhagic shock. None of the trials had mortality as a primary outcome. Three out of six studies that reported at least one death showed better survival in children resuscitated with colloids compared with crystalloids (Peto fixed odds ratio ranging from 0.18 (95\% confidence interval 0.02 to 1.42 ) to 0.48 (0.06 to 3.99)). Studies contributing data on mortality had some methodological limitations so caution is recommended when interpreting this finding. Studies were heterogeneous so combined estimates were not calculated. The review was limited by inclusion of only published studies.

Conclusions The current evidence on choice of fluids for resuscitation in children with infections is weak. While existing trials have provided important evidence in malaria and dengue, resuscitation in children with paediatric sepsis, for which colloids could theoretically be of benefit, has not been studied. The evidence from existing studies is not robust enough to make any definitive recommendations over the choice of resuscitation fluid and a definitive trial is required to address this.

\section{INTRODUCTION}

Circulatory shock is a major cause of morbidity and mortality among children requiring emergency care. ${ }^{1}$
The leading cause of circulatory failure in children is hypovolaemia, usually secondary to severe infection. ${ }^{2}$ Early and rapid fluid resuscitation with isotonic solutions is the cornerstone of management. For children, however, there is still no clear consensus over the choice of resuscitation fluid, and colloidal solutions (such as human albumin solution) might be better than the cheaper crystalloids (such as normal saline).$^{3-11}$ Although physiological explanations have been advanced to support potential benefits of colloids over crystalloids, the current evidence does not support these. ${ }^{3-5}$ Earlier Cochrane meta-analyses concluded that human albumin solution resulted in increased mortality, ${ }^{356}$ but these conclusions were disputed and a subsequent meta-analysis showed that use of human albumin solution or $0.9 \%$ saline resulted in similar survival. ${ }^{4}$ This conclusion was greatly influenced by the results of a trial of human albumin solution compared with saline in 7000 adults in Australia and New Zealand (SAFE study), which reported similar survival in both treatment arms. ${ }^{12}$ A non-significant trend towards improved survival was noted in the subgroup of patients with sepsis treated with human albumin solution. Successive meta-analyses, however, have consistently found that crystalloids are preferable to colloids in patients with burns, trauma, surgery, traumatic head injury, and gastroenteritis. ${ }^{3-7912}$ Although the debate in adults is far from over, there is also considerable uncertainty in the management and choice of fluids in paediatric shock.

Conclusions drawn from trials in adults cannot simply be extrapolated to children for several reasons. Firstly, children have a different physiological response to severe illness. The development of low cardiac index and high systemic vascular resistance is common in community acquired septic shock (cold shock), whereas in adults, low cardiac index and low vascular resistance (warm shock) is common. ${ }^{13}$ Secondly, children have a larger ratio of surface area to volume and therefore lose more fluid than adults and also often respond well to aggressive volume resuscitation as they tolerate larger fluid volumes per kilogram of body weight. ${ }^{14}$ Finally, children are at increased risk of meningoencephalitis, and, as the presentation of paediatric shock often includes a degree of impaired 
consciousness, this possibility cannot be excluded in fluid resuscitation guidelines. In this circumstance, there is a notional possibility that resuscitation with colloidal solutions could be a safer option than crystalloid solutions, which might increase the risk of exacerbating brain swelling or increases in intracranial pressure. For these and several other reasons separate paediatric guidelines have been developed for the emergency assessment and treatment of children. ${ }^{15-17}$ Current paediatric practice, however, continues to be influenced by the first Cochrane meta-analysis. A survey conducted after the publication of an earlier metaanalysis, which reported an increased risk of mortality in patients resuscitated with human albumin solution, showed a marked decline in the use of albumin in paediatric intensive care units in the UK. ${ }^{18}$ The survey also highlighted the widespread lack of written guidelines for fluid management. For low income countries, international guidelines follow those developed by the World Health Organization, which currently recommends different fluids and volumes for treating shock depending on the underlying disease condition. ${ }^{17} 1920$

We summarised the evidence available from trials dealing with management of shock in children with severe infection. We included sepsis and sepsis-like conditions, for which there are equipoise or theoretical advantages for using colloids. We excluded studies in children with burns, trauma, surgical conditions, and gastroenteritis as there is substantial agreement that crystalloids are preferable..$^{3-7912}$ To avoid heterogeneity in populations of patients, a criticism of previous meta-analyses ${ }^{21}$ we also excluded studies in neonates because of differences in presentation of clinical disease and host physiology.

\section{METHODS}

Information sources -We searched Medline (1950 to September 2008), Embase (1980 to September 2008), Pubmed, and the Cochrane library. Reference lists for the initial studies retrieved were examined to identify any additional relevant studies missed by the electronic searches. We also reviewed the studies reported in the previous Cochrane meta-analyses.

Search strategy-There were no language restrictions but we limited searches to children aged 1 month to 12 years. We excluded studies that reported fluid resuscitation restricted to diarrhoea, trauma, and surgery. Our strategy was developed by breaking the review question into exposure, intervention, population, publication language, and key words as recommended by the National Health Service (NHS) Centre for Reviews and Dissemination. ${ }^{22}$ Highly sensitive Medline search filters were also used. ${ }^{23}$ Only published studies available up to September 2008 were included, and we did not contact authors of the relevant studies for any unpublished work. Details of the search strategy are in appendix 1 on bmj.com.

Study selection - Titles and abstracts of all the studies retrieved were reviewed to identify relevant studies for inclusion. We obtained and assessed full transcripts of potentially relevant studies to ascertain whether they met the inclusion criteria. Disagreements were resolved with the input of the third author.

Eligibility criteria-The studies were selected if they were controlled trials, quasi-randomised trials, cohort studies, and randomised controlled trials that compared different intravenous fluids, given as boluses, for the treatment of shock in children aged between 1 month and 12 years. Included trials studied crystalloids versus colloids, crystalloids versus crystalloids, or colloids versus colloids. We selected trials that investigated fluid resuscitation in any infectious disease anywhere in the world, including sepsis, malaria, dengue, and any other infectious cause that could be traced. We excluded studies that reported fluid resuscitation in diarrhoeal disease, burns, and trauma or injury cases, and where fluid was given for a surgical procedure or anaesthesia purposes (see appendix 2 on bmj.com for details).

Data collection process - The two investigators independently assessed the methodological quality of the selected studies using a pre-developed proforma. Information on study design, adequacy of randomisation, degree of allocation concealment, blinding/masking, and follow-up were assessed. When there was disagreement, the opinion of the third author was sought.

Data items - Two unblinded investigators (SA and $\mathrm{HL}$ ) extracted the data, collecting information on category of disease, authors, year of publication, country where the study was conducted, study design (randomisation, allocation, masking), number of participants, fluid interventions given, outcome measures used, side effects of interventions, and mortality.

Synthesis of results - We report a qualitative description of studies when statistical pooling was not possible and a quantitative summary when it was. Clinical and methodological heterogeneities were assessed by reviewing and comparing the patient populations, interventions, outcomes, disease spectrum covered, study design, and risk of bias. We used the RevMan software to assess the risk of bias by reviewing the methods used in the studies for adequacy of sequence generation, allocation concealment, blinding, completeness of the data, and selective reporting. ${ }^{2425}$

Summary measures-For studies that compared crystalloids with colloids (any colloid or human albumin solution alone) and reported at least one death (in either arm), we calculated the Peto odds ratio using the fixed effects model for each study, derived a forest plot, and used a $\chi^{2}$ test for statistical heterogeneity. Studies judged to have clinical or methodological heterogeneity were not combined.

\section{RESULTS}

\section{Study selection}

We identified 1016 studies from our search, of which 120 studies were found to be relevant. Twenty one studies were selected from the relevant studies, full copies retrieved, and more detailed methodological evaluation done. Only nine studies were finally identified as meeting the inclusion criteria (fig 1), and 12 studies ${ }^{1226-36}$ were excluded at this stage (see appendix 2 on bmj.com). 


\section{Study characteristics}

The total number of patients reported in the studies was 1198 , with the largest study reporting 512 patients and the smallest 27 (table). All nine studies were conducted in low income settings, four in Kenya ${ }^{37-40}$ and five in Asia. ${ }^{41-45}$ Four studies were in children with malaria, four in those with dengue shock syndrome, and one study in those with sepsis.

\section{Risk of bias within studies}

Two trials conducted in children with severe malaria did not have adequate sequence generation, had no allocation concealment, were open labelled, and were quasi-randomised. ${ }^{370}$ Two other studies had adequate sequence generation and allocation concealment but were unblinded and had a similar follow-up to hospital discharge. The three trials conducted in children with dengue shock syndrome in Vietnam were all double blind randomised trials with adequate allocation concealment and adequate sequence generation. ${ }^{41-43}$ The fourth trial in dengue patients was conducted in the Philippines and reported that there was systematic allocation, though this was not described in detail. Followup in the Philippines study was only for the duration of stay in the intensive care unit, and all the children who died were reported to have had a protocol violation. The trial conducted in children with septic shock in India was open labelled, had adequate randomisation and adequate sequence generation, and the period of follow-up was also described.

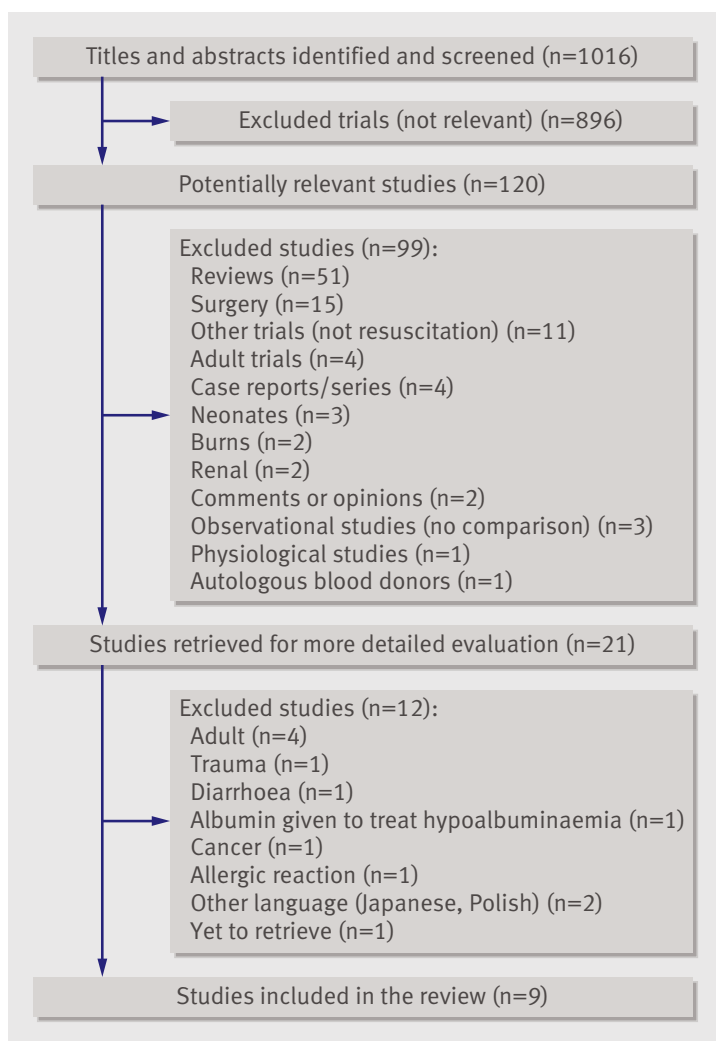

Fig 1 Summary of trials on fluid resuscitation in children retrieved from searches

\section{Study findings}

Our main outcomes were efficacy in the treatment of shock, mortality, and reported adverse events.

\section{Treatment of shock}

Most studies had resolution of shock and achievement of haemodynamic stability as an outcome. Different variables were used to define these, including the volume of fluids needed for resuscitation, the time taken for haemodynamic stabilisation, the need for "rescue" fluids, acid-base normalisation and recovery, duration of shock, and any subsequent episodes of shock. Generally, there were no significant differences in the recovery from shock in patients resuscitated with various fluids compared in trials in sepsis or malaria. The trials conducted in dengue shock reported a superior efficacy of colloids over crystalloids for resolution of severe shock, with faster restoration of cardiac index and normalisation of packed cell volume or blood pressure, or both.

In children with severe malaria, there were similar improvements in central venous pressure with equivalent volumes of either $0.9 \%$ saline or $4.5 \%$ human albumin solution. ${ }^{37}$ In other trials without invasive monitoring, there were similar reductions in acidosis and other features of shock ${ }^{3839}$ in children receiving human albumin solution or saline and in those receiving albumin or Gelofusine (a gelatin based colloid). ${ }^{40}$

Three studies in children with dengue shock, conducted by the same research group in Vietnam, applied similar study methods across all their trials. In the largest of the three trials, the primary end point was the requirement for rescue by colloidal fluids at any time point. Rescue colloid was given if there was narrowing on response in pulse pressure accompanied with peripheral shutdown or rising packed cell volume, or both. ${ }^{43}$ The study also compared restoration of cardiac index, normalisation of packed cell volume, and normalisation of blood pressure. For children with severe shock, defined as pulse pressure $\leq 10 \mathrm{~mm} \mathrm{Hg}$, colloids resulted in better resolution of severe shock quantified by the secondary end points when compared with Ringers lactate. In moderate shock (pulse pressure $>10 \mathrm{~mm} \mathrm{Hg}$ but $\leq 20 \mathrm{~mm} \mathrm{Hg}$ ), Ringers lactate had similar results to colloids. ${ }^{43}$ The Philippines trial, which enrolled 27 children with dengue shock and compared hydroxyethyl starch (6\% Haes-Steril) with Ringers lactate, reported that the starch controlled shock for longer and resulted in less need for other rescue treatment other than Ringers lactate.

The study in paediatric sepsis involved 60 patients and showed similar haemodynamic stability at 6 and 12 hours among those resuscitated with saline or gelatin polymer (Haemaccel)..$^{45}$ Haemodynamic variables used to assess resolution of shock included heart rate, capillary refill time, pulse volume, and blood pressure. The authors noted that resuscitation with saline required $20 \mathrm{ml} / \mathrm{kg}$ more than the volume of gelatin polymer required to achieve haemodynamic stability, measured by capillary wedge pressure. 


\section{Characteristics of studies retrieved on paediatric fluid resuscitation}

\begin{tabular}{|c|c|c|c|c|c|}
\hline Study & Methods & Participants & Interventions & Outcomes & Comments \\
\hline Akech $2006^{40}$ & $\begin{array}{l}\text { Controlled trial (quasi- } \\
\text { randomisation). Sequential blocks } \\
\text { of } 10 \text {. No blinding. No allocation } \\
\text { concealment. Follow-up to } \\
\text { discharge from hospital for adverse } \\
\text { events }\end{array}$ & $\begin{array}{l}88 \text { children with } \\
\text { malaria age }>3 \text { months } \\
\text { with metabolic } \\
\text { acidosis (base deficit } \\
>8 \mathrm{mmol} / \mathrm{l}) ; \\
\mathrm{Hb}>50 \mathrm{~g} / \mathrm{l} \text {; plus } \\
\text { clinical feature of } \\
\text { shock }\end{array}$ & $\begin{array}{l}\text { Gelofusine ( } \mathrm{n}=44) ; 4.5 \% \text { HAS } \\
\text { ( } \mathrm{n}-44) . \text { Admission: bolus } 20 \text { or } \\
40 \mathrm{ml} / \mathrm{kg} \text { (if hypotensive). Further } \\
20 \mathrm{ml} / \mathrm{kg} \text { if shock present at } 1 \text { hour }\end{array}$ & $\begin{array}{l}\text { Resolution of shock. Resolution of } \\
\text { acidosis at } 1 \text { and } 8 \text { hours. In } \\
\text { hospital death. Adverse events. } \\
\text { Neurological sequelae. Allergic } \\
\text { reactions }\end{array}$ & $\begin{array}{l}\text { Quasi-randomisation. Inadequate } \\
\text { allocation concealment. } \\
\text { Inadequate sequence generation. } \\
\text { Colloid } v \text { colloid comparison }\end{array}$ \\
\hline Cifra $2003^{44}$ & $\begin{array}{l}\text { Quasi-randomised trial. Patients } \\
\text { allocated "systematically." } \\
\text { Alternate allocation. No } \\
\text { information on blinding. All } \\
\text { outcomes in hospital. No loss to } \\
\text { follow-up }\end{array}$ & $\begin{array}{l}\text { Dengue shock } \\
\text { syndrome; } \\
27 \text { children }\end{array}$ & $\begin{array}{l}6 \% \text { Hydroxyethyl starch (Haes- } \\
\text { Steril) }(n=11) ; \text { Ringers lactate } \\
(n=16)\end{array}$ & $\begin{array}{l}\text { Duration of control of shock, } \\
\text { frequency of recurrence of shock, } \\
\text { length of ICU stay, mortality }\end{array}$ & $\begin{array}{l}\text { Inadequate allocation } \\
\text { concealment. Inadequate } \\
\text { sequence generation }\end{array}$ \\
\hline Dung $1999^{41}$ & $\begin{array}{l}\text { RCT. Allocation concealment with } \\
\text { numbered opaque envelopes. } \\
\text { Double blind with opaque } \\
\text { envelopes in blocks of } 10 \text {. Fluid } \\
\text { masked with black opaque } \\
\text { containers. Follow-up to hospital } \\
\text { discharge }\end{array}$ & $\begin{array}{l}\text { Dengue shock } \\
\text { syndrome; } 50 \\
\text { children aged } \\
5-15 \text { years who had } \\
\text { not received IV fluid } \\
\text { therapy during current } \\
\text { illness }\end{array}$ & $\begin{array}{l}\text { Dextran } 70(n=12) ; 3 \% \text { Gelafundin } \\
(n=13) ; \text { Ringers lactate }(n=13) ; \\
\text { normal saline }(n=12) . \text { Bolus } \\
20 \mathrm{ml} / \mathrm{kg} \text { over } 1 \text { hour, } 10 \mathrm{ml} / \mathrm{kg} \text { over } \\
2 \text { nd hour }\end{array}$ & $\begin{array}{l}\text { Recovery from shock (pulse } \\
\text { pressure } \leq 20 \mathrm{~mm} \mathrm{Hg} \text { ), duration and } \\
\text { No of episodes of shock, } \\
\text { improvements in cardiac output } \\
\text { and packed cell volume, and, } \\
\text { requirements for further fluid } \\
\text { resuscitation }\end{array}$ & $\begin{array}{l}\text { Adequate allocation concealment } \\
\text { and adequate sequence } \\
\text { generation. No deaths }\end{array}$ \\
\hline Maitland $2003^{37}$ & $\begin{array}{l}\text { Controlled trial (quasi- } \\
\text { randomisation). Alternate } \\
\text { systematic allocation. Allocation } \\
\text { also based on availability of study } \\
\text { fluid. No blinding. No allocation } \\
\text { concealment. Follow-up to } 48 \text { hours } \\
\text { after admission for haemodynamic } \\
\text { variables and blood gases } \\
\text { (acidosis) }\end{array}$ & $\begin{array}{l}53 \text { children with } \\
\text { severe malaria aged } \\
6 \text { months-12 years. } \\
\text { Metabolic acidosis } \\
\text { (base deficit } \\
>8 \mathrm{mmol} / \mathrm{l}) \text {. Divided } \\
\text { into severe anaemia } \\
(\mathrm{Hb}<50 \mathrm{~g} / \mathrm{l} \text { ) or no } \\
\text { severe anaemia }\end{array}$ & $\begin{array}{l}0.9 \% \text { saline }(n=20) ; 4.5 \% \text { HAS } \\
(n=32) ; \text { saline and HAS }(n=1) . \\
\text { Aliquots of } 10 \mathrm{ml} / \mathrm{kg} \text { given to } \\
\text { achieve } \mathrm{CVP} 5-8 \mathrm{~cm} \mathrm{H} \mathrm{H}_{2} \mathrm{O} \text {. Bolus of } \\
10-40 \mathrm{ml} / \mathrm{kg} \text { given over } 1 \text { st hour } \\
\text { after admission }\end{array}$ & $\begin{array}{l}\text { Resolution of acidosis/base deficit } \\
\text { reduction at } 8 \text { hours, CVP } 5-8 \mathrm{~cm} \\
\mathrm{H}_{2} \mathrm{O} \text { and, improvement of } \\
\text { haemodynamic indices }\end{array}$ & $\begin{array}{l}\text { Inadequate allocation } \\
\text { concealment and inadequate } \\
\text { sequence generation }\end{array}$ \\
\hline Maitland $2005^{38}$ & $\begin{array}{l}\text { RCT. No blinding. Allocation } \\
\text { concealment with opaque } \\
\text { envelopes. Follow-up to discharge } \\
\text { from hospital for adverse events }\end{array}$ & $\begin{array}{l}150 \text { children with } \\
\text { severe malaria, age } \\
6 \text { months- } 12 \text { years. } \\
\text { Metabolic acidosis } \\
\text { (base deficit } \\
>8 \mathrm{mmol} / \mathrm{l}), \mathrm{Hb}>50 \mathrm{~g} / \mathrm{l}\end{array}$ & $\begin{array}{l}0.9 \% \text { saline ( } \mathrm{n}=61), 4.5 \% \text { HAS } \\
(\mathrm{n}=56), \text { no bolus }(\mathrm{n}=33) \text {. Moderate } \\
\text { acidosis (base deficit } 8-15 \mathrm{mmol} / \mathrm{l}) \text { : } \\
\text { received } 20 \mathrm{ml} / \mathrm{kg}(\text { saline and HAS) } \\
\text { or no bolus (control). Severe } \\
\text { acidosis (base deficit }>15 \mathrm{mmol} / \mathrm{l}) \\
\text { received } 40 \mathrm{ml} / \mathrm{kg} \text {, no control } \\
\text { group. Rescue if hypotensive or } \\
\text { oliguria }\end{array}$ & $\begin{array}{l}\text { Resolution of acidosis/base deficit } \\
\text { reduction at } 8 \text { hours, in-hospital } \\
\text { death, neurological sequelae, need } \\
\text { for rescue therapies }\end{array}$ & $\begin{array}{l}\text { Adequate allocation concealment. } \\
\text { Computer generated } \\
\text { randomisation sequence } \\
\text { produced by an independent } \\
\text { statistician, information provided } \\
\text { by authors of review who } \\
\text { conducted studies }\end{array}$ \\
\hline Maitland $2005^{39}$ & $\begin{array}{l}\text { RCT. Allocation concealment with } \\
\text { sealed card system. No blinding. } \\
\text { Follow-up to discharge from } \\
\text { hospital for adverse events }\end{array}$ & $\begin{array}{l}61 \text { children with } \\
\text { symptomatic severe } \\
\text { malaria anaemia, age } \\
>2 \text { months plus } \\
\text { metabolic acidosis } \\
\text { (base deficit } \\
>8 \mathrm{mmol} / \mathrm{l} \text { ) }\end{array}$ & $\begin{array}{l}0.9 \% \text { saline }(n=20), 4.5 \% \text { HAS } \\
(n=23) \text {, or control (no bolus) }(n=18) \text {. } \\
\text { Bolus } 20 \mathrm{ml} / \mathrm{kg} \text { of normal saline or } \\
\text { albumin over } 1 \text { hour while awaiting } \\
\text { blood transfusion. }\end{array}$ & $\begin{array}{l}\text { Resolution of acidosis/base deficit } \\
\text { reduction at } 8 \text { hours, in-hospital } \\
\text { death, neurological sequelae }\end{array}$ & $\begin{array}{l}\text { Adequate allocation concealment. } \\
\text { Computer generated } \\
\text { randomisation sequence } \\
\text { produced by independent } \\
\text { statistician, information provided } \\
\text { by authors of review who } \\
\text { conducted studies }\end{array}$ \\
\hline Ngo $2001^{42}$ & $\begin{array}{l}\text { RCT. Double blind with fluid } \\
\text { masked using black opaque } \\
\text { containers. Allocation concealment } \\
\text { with opaque envelopes in blocks of } \\
\text { 10. Follow-up to hospital discharge }\end{array}$ & $\begin{array}{l}230 \text { children with } \\
\text { Dengue shock } \\
\text { syndrome, aged } \\
5-15 \text { years, had not } \\
\text { received IV fluid } \\
\text { therapy during current } \\
\text { illness }\end{array}$ & $\begin{array}{l}\text { Dextran } 70(n=55), 3 \% \text { gelatin } \\
\text { (Gelafundin) }(n=56) \text {, Ringers } \\
\text { lactate }(n=55), \text { or normal saline } \\
(n=56) . \text { Bolus } 20 \mathrm{ml} / \mathrm{kg} \text { over } 1 \text { hour, } \\
10 \mathrm{ml} / \mathrm{kg} \text { over } 2 \text { nd hour. } 8 \text { children } \\
\text { had dengue haemorrhagic fever } \\
\text { grade IV and not randomised }\end{array}$ & $\begin{array}{l}\text { Recovery from shock (pulse } \\
\text { pressure } \leq 20 \mathrm{~mm} \mathrm{Hg} \text { ), duration and } \\
\text { No of episodes of shock, } \\
\text { improvements in cardiac output } \\
\text { and packed cell volumes, } \\
\text { requirements for further fluid } \\
\text { resuscitation }\end{array}$ & $\begin{array}{l}\text { Adequate sequence generation } \\
\text { and adequate allocation } \\
\text { concealment. No deaths }\end{array}$ \\
\hline $\begin{array}{l}\text { Upadhyay } \\
2005^{45}\end{array}$ & $\begin{array}{l}\text { RCT. Open label, randomised. } \\
\text { Random tables used to generate } \\
\text { numbers. Allocation concealment } \\
\text { with sealed envelopes and kept } \\
\text { with one investigator. Monitoring } \\
\text { till } 6 \text { hours after stability then till } \\
\text { recovery }\end{array}$ & $\begin{array}{l}60 \text { children with } \\
\text { sepsis, age } 1 \text { month } \\
-12 \text { years. Septic } \\
\text { shock, without } \\
\text { clinical evidence of } \\
\text { organ failure at } \\
\text { admission or } \\
\text { hypotension }\end{array}$ & $\begin{array}{l}\text { Normal saline }(n=31) \text { or, } \\
\text { Haemaccel }(n=29) \text {. Bolus } 20 \mathrm{ml} / \mathrm{kg} \\
\text { of } 0.9 \% \text { saline or Haemaccel till } \\
\text { haemodynamically stable or if CVP } \\
>10 \mathrm{~mm} \mathrm{Hg}\end{array}$ & $\begin{array}{l}\text { Haemodynamic stabilisation (heart } \\
\text { rate, capillary refill time, pulse } \\
\text { volume, blood pressure in normal } \\
\text { range), plasma volume at end of } \\
\text { fluid resuscitation, incidence of } \\
\text { organ dysfunction }\end{array}$ & $\begin{array}{l}\text { Adequate allocation concealment } \\
\text { and adequate sequence } \\
\text { generation }\end{array}$ \\
\hline Wills $2005^{43}$ & $\begin{array}{l}\text { RCT. Computer generated random } \\
\text { numbers. Double blind treatment } \\
\text { packs in sealed special cardboard } \\
\text { containers, identified only by study } \\
\text { number. Independent staff not } \\
\text { involved in care prepared packs } \\
\text { and randomisation. Pre-sealed and } \\
\text { pre-labelled envelopes used in } \\
\text { emergency. Allocation } \\
\text { concealment. Follow-up to } \\
\text { discharge from hospital }\end{array}$ & $\begin{array}{l}512 \text { children with } \\
\text { clinical dengue shock } \\
\text { syndrome, aged } \\
2-15 \text { years }\end{array}$ & $\begin{array}{l}\text { Ringers lactate }(\mathrm{n}=128), 6 \% \\
\text { Detran70 }(\mathrm{n}=193), \text { or } 6 \% \\
\text { hydroxyethyl starch ( } \mathrm{n}=191) \text {. } \\
\text { Group } 1=(\text { moderate shock: pulse } \\
\text { pressure }>10 \text { and } \leq 20 \mathrm{~mm} \mathrm{Hg}) \\
\text { Dextran, starch, or Ringers lactate. } \\
\text { Group } 2=(\text { severe shock: pulse } \\
\text { pressure }<10 \mathrm{~mm} \mathrm{Hg} \text { ) allocated to } \\
\text { Dextran or starch and given } \\
15 \mathrm{ml} / \mathrm{kg} \text { over } 1 \text { hour, } 10 \mathrm{ml} / \mathrm{kg} \text { over } \\
2 \mathrm{nd} \text { hour }\end{array}$ & $\begin{array}{l}\text { Requirement for rescue colloid at } \\
\text { any time after infusion of study } \\
\text { fluid, time taken to achieve initial } \\
\text { cardiovascular stability (pulse } \\
\text { pressure } \geq 25 \text { and systolic blood } \\
\text { pressure } \geq 80 \mathrm{~mm} \text { Hg for minimum } \\
\text { of } 2 \text { hours), volumes of rescue } \\
\text { colloid and total parenteral fluid } \\
\text { required, No of days in hospital, } \\
\text { change in packed cell volume, } \\
\text { allergic reactions }\end{array}$ & $\begin{array}{l}\text { Adequate sequence generation } \\
\text { and adequate allocation } \\
\text { concealment }\end{array}$ \\
\hline
\end{tabular}


Other end points used in the studies to compare efficacy of treatment of shock included use of secondary resuscitation strategies and incidence of organ failure.

\section{Mortality}

None of the studies were designed or adequately powered to examine mortality as a primary outcome. The four trials in dengue enrolled 819 children and reported five deaths. Because of the expected low mortality in dengue, this was not a stated end point. Therefore no conclusions can be drawn about the survival benefit between colloids and crystalloids in this disease.

A total of 352 children were enrolled in fluid expansion trials in children with severe malaria. Two studies included 51 children randomised to a "no bolus" (control) strategy. ${ }^{3839}$ One study that compared 0.9\% saline with human albumin solution showed a significant overall reduction in mortality in the albumin group $(\mathrm{P}=0.013)$ and in the high risk subgroup, where acidosis and shock was complicated by coma $(\mathrm{P}=0.002)$. There were, however, no differences between the fluid intervention arms in cases without coma $(\mathrm{P}=0.7) .^{38}$ The survival advantage was also noted in the trial of human albumin solution compared with Gelofusine (a gelatin polymer), in which mortality was lower in the albumin group $(\mathrm{P}=0.06)$, particularly in the subgroup with coma $(\mathrm{P}=0.04) .^{40}$

The trial conducted in children with sepsis found no difference in mortality with fluids used: 9/31 (29\%) saline recipients died compared with $9 / 29$ (31\%) in the gelatin polymer group

\section{Adverse events}

There was a non-significant increase in neurological sequelae with human albumin solution compared with other fluids in children who survived severe malaria: 9/136 (7\%) with albumin, 2/95 (2\%) with saline, and 1/37 (3\%) with Gelofusine. ${ }^{37-40}$ One episode of allergic reaction was reported in a child receiving Gelofusine. ${ }^{40}$ Pulmonary oedema, unrelated to the intervention, was reported in two of $61(3 \%)$ children who received saline in one trial. ${ }^{38}$ In children with dengue who received dextran, 15/193 (8\%) developed signs of severe reactions, which included fever and

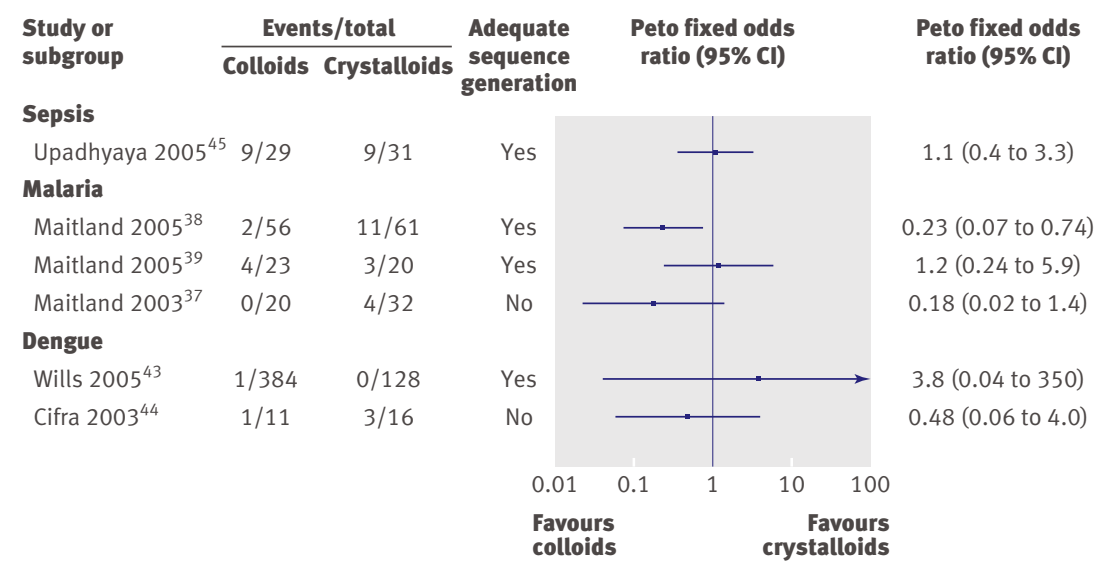

Fig 2 | Comparison of mortality in children resuscitated with colloids or crystalloids rigors without cardiorespiratory compromise, while one of 191 children who received starch $6 \%$ hydroxyethyl starch) developed an afebrile event with an urticarial rash in the same trial. ${ }^{43}$ In another dengue trial 5/56 (9\%) children who received gelatin polymer (Gelafundin) and one (1/70) who received dextran developed allergic reactions but without signs of cardiovascular compromise. ${ }^{42}$ One child who received gelatin suffered severe epistaxis and required a blood transfusion, and another who received dextran developed a haematoma at an injury site. ${ }^{42}$ The Indian trial in children with sepsis reported no adverse reactions. ${ }^{45}$

\section{Quantitative data synthesis}

Colloids versus crystalloids

We selected six trials (three malaria trials, two dengue trials, and one sepsis trial) that reported at least one death to compare colloids and isotonic crystalloids (normal saline or Ringers lactate). ${ }^{37-3943-45}$ These included 811 participants, 523 randomised to colloids and 288 to crystalloids, and reported 48 deaths (17 in those receiving colloids). Though the forest plots indicated no significant heterogeneity $\left(\chi^{2}=2.66, \mathrm{P}=0.26\right)$, we chose not to provide a composite estimate because of clinical heterogeneity in the a priori risk of mortality between the different conditions (dengue, severe malaria, and sepsis). Three out of the six studies showed better survival in children resuscitated with colloids compared with crystalloids, but the wide confidence intervals in these studies caution against interpreting this as a true effect of treatment. Figure 2 summarises the results.

\section{Albumin crystalloids}

Because of the ongoing debate we examined the effect of human albumin solution in resuscitation on survival. ${ }^{571146-48}$ The only trials included were those in children with severe malaria (fig 3). We found important clinical heterogeneity in these studies as one enrolled children with severe anaemia, in whom fluid resuscitation was given as pre-transfusion management, ${ }^{39}$ while the two other studies excluded children with severe malaria anaemia, ${ }^{3738}$ hence we could not calculate combined summary estimates. The largest of these trials showed a significant reduction in mortality for children resuscitated with human albumin solution compared with saline ${ }^{38}$; another trial showed non-significantly reduced mortality ${ }^{37}$; while the third trial (in those with severe malaria anaemia) showed no difference in survival. ${ }^{38}$ Another trial in children with severe malaria that compared human albumin solution with Gelofusine reported a non-significant reduction in mortality in those resuscitated with human albumin solution. ${ }^{40}$ Mortality in the human albumin solution arm was 1/44 (2\%) compared with $7 / 44(16 \%)$ in the Gelofusine arm (Peto odds ratio $0.20,95 \%$ confidence interval 0.05 to $0.83, \mathrm{P}=0.03$ ).

\section{Sepsis}

In the only trial included, there was no difference in the risk of mortality between saline and gelatin polymer (Peto odds ratio $1.10,0.37$ to $3.29, \mathrm{P}=0.87) .{ }^{45}$ 


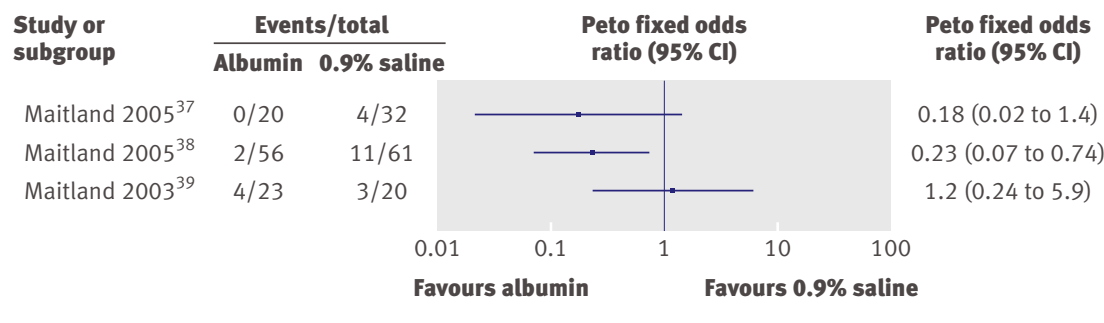

Fig 3 | Comparison of mortality in children resuscitated with albumin or crystalloids

\section{Risk of bias across studies}

The studies conducted in Vietnamese children with dengue had a low risk of bias but limited information about mortality. ${ }^{41-43}$ Most information on the effect of colloids on mortality came from studies in children with severe malaria, which were unblinded and small in size and two had quasi-randomisation - all factors that increase risk of bias. ${ }^{37-40}$ The study in sepsis also had high risk of bias because it was small in size and had no sample size calculation. The study in dengue in the Philippines had a high risk of bias because of the study design. ${ }^{44}$

\section{DISCUSSION}

\section{Summary of evidence}

This review of fluid resuscitation in paediatric shock in severe infection found few trials and showed that there is insufficient evidence to support the preferential use of colloids or crystalloids in paediatric sepsis. While this finding is in agreement with meta-analyses in adults, which found a similar survival benefit in resuscitation with either colloids or crystalloids, recommendations in adults were informed by well powered trials. This contrasts with the evidence from paediatrics, which can be drawn only from trials too small in size to adequately inform a meta-analysis with respect to the questions of survival, management guidelines, or policy. The randomised trials in dengue septic shock involved a large number of patients, but as mortality was rare, these studies were also unsuitable to address this particular question.

There is substantial evidence indicating that colloids are better than crystalloids for treating severe shock in dengue septic shock, but both have similar efficacy in moderate shock. As severe shock in dengue septic shock is much less common than moderate shock, crystalloids remain the mainstay for treatment of this condition. ${ }^{41-4349}$ In malaria, the analysis indicated a superior survival benefit with human albumin solution compared with either saline or another colloid (Gelofusine), but the results were insufficient to inform policy because of the small sample size and some limitations of the study design. The single trial in children with sepsis was too small to detect differences in mortality but showed that a larger volume of crystalloid was required to achieve the same resuscitation end point as colloid.

The apparent reduction in mortality in children with severe malaria who received human albumin solution as fluid expansion is interesting but needs further clarification. Small trials tend to overestimate the overall effect. $^{50}$ Together with some methodological aspects, the interpretation of results from a single site can also contribute to an overestimated effect of treatment. ${ }^{51-53}$ Nevertheless, the results merit confirmation in a definitive trial, and one is currently underway (www.feasttrial.org).

This review brings into focus a few important issues. Firstly, there are surprisingly few trials examining fluid resuscitation strategies in children. Fluid resuscitation is common in modern paediatrics, with recommendations based on consensus or expert opinion rather than results of definitive studies or meta-analysis. Secondly, as the studies were not designed with mortality as the primary outcome and used different definitions of resolution of shock as outcomes, it would be methodologically incorrect and misleading to combine the results to obtain a summary estimate. Thirdly, of the nine trials included, all were conducted in resource poor countries, despite fluid resuscitation practice being much less common.

International paediatric treatment guidelines, which have been prospectively evaluated, indicate that $60 \mathrm{ml} / \mathrm{kg}$ of isotonic resuscitation fluid given in the first hour of development of shock leads to a ninefold reduction in mortality, ${ }^{54-56}$ and every hour that hypovolaemia is uncorrected results in doubling of mortality. ${ }^{546}$ Currently there are no evidenced based recommendations to guide the optimal choice of fluid for resuscitation in these or other guidelines. Acute bacterial infections, together with malaria in Africa and dengue in South East Asia, are common causes of hospital admission and are one of the commonest infectious causes of death. Few children with sepsis and severe malaria receive supportive treatments, including fluid resuscitation, which is generally reserved for children with advanced features of shock. ${ }^{1920}$ The trials included in this meta-analysis were conducted mainly on hospital wards with limited sophisticated life support equipment. They represent proof of principle trials, aimed at generating important data to guide the next stage (late phase clinical trials or guideline development). The focus was on fluid responsive rather than fluid refractory shock, and the relevance of this meta-analysis to children requiring inotropic support is uncertain.

The question of which fluid is ideal for resuscitation remains unanswered and hence is pertinent globally. ${ }^{4-71057}$ Differences in physiological dysfunction, speed of the development of shock, complications, and case fatality before intervention frustrate the development of a single fluid resuscitation strategy appropriate for all contexts. Consequently, debate over the merits of volume resuscitation with colloids or crystalloids could have different relevance because of the distinct pathophysiological mechanisms that are involved in different underlying diseases in children. For example, the tempo of dengue shock is generally slow, with shock developing over many hours or days because of haemoconcentration as a result of severe 


\section{WHAT IS ALREADY KNOW ON THIS TOPIC}

There is no overall clear benefit for the use of colloids over crystalloids for volume

resuscitation in patients of all ages

Volume expansion with crystalloids results in better survival in patients with trauma, gastroenteritis, burns, and traumatic brain injury

Volume expansion with human albumin solution or other colloids could be better than crystalloids in specific groups of patients with sepsis from various causes

\section{WHAT THIS STUDY ADDS}

Compared with crystalloids, there is some weak evidence that volume expansion with colloids could result in better survival in children with certain severe infections

Few studies have compared the survival benefit of colloids versus crystalloids in those with sepsis, in whom colloids might be beneficial

capillary leak. This contrasts with shock in sepsis and possibly malaria, which progresses rapidly with a high risk of early mortality. ${ }^{58}$ In addition, for those with impaired consciousness there is the potential risk of brain swelling for sepsis and malaria, whereas neurological complications are rare in dengue shock. ${ }^{43}$

Our review points to an improved outcome for children receiving colloids. Whether viewed as tantalising or inconsequential evidence, it indicates that this should be evaluated in a definitive trial before any recommendations can be made. The pitfalls of colloidal fluid resuscitation include allergic or febrile reactions, effects on coagulation, and renal toxicity. Albumin has the best safety profile but is in short supply and therefore expensive. Gelatins have a higher incidence of allergic reaction but their effect on coagulation, like human albumin solution, is largely dilutional. ${ }^{46}$ Allergic and febrile reactions also occur with dextrans. ${ }^{4346}$ Higher molecular weight starches might cause renal toxicity but only if given in large doses. ${ }^{560}$ In the studies we reviewed, synthetic colloids did not result in renal toxicity, coagulation, or bleeding problems ${ }^{40}$ but bleeding problems have been reported in other clinical studies. ${ }^{61}$ Finally, none of these solutions are routinely available in sub-Saharan African countries and would require the results of a well powered trial and cost analysis to inform future policy.

\section{Limitations}

The major limitation was that we considered only published studies, which could introduce reporting bias. This was not evident from a visual inspection of the funnel plot (not shown), which was symmetrical. Too few studies included children with sepsis, and the observed effect of colloids on mortality was limited to trials in severe malaria, which were unblinded and had a potential for bias because of limitations of study design. $^{25}$

\section{Conclusions}

Though this review has some interesting findings, it did not identify sufficient evidence to inform the preferential use of either colloids or crystalloids for treating paediatric shock. As the reported trials were small and dealt with diverse morbidities (dengue, sepsis, and malaria) and thus did not approach the management of shock in an integrated manner, their findings would be difficult to generalise across the paediatric population. Broad based trials are needed to compare the efficacy of fluid expansion of colloids and crystalloids in children. Design of such trials, however, will have to take into consideration the safety concerns of certain colloids.

Contributors: SA and HL were responsible for the literature review and initial synthesis of results. SA was responsible for the data analysis. KM conceived the idea for the study and supervised literature review and results summaries. All authors contributed to the writing of the paper and approved the final draft. KM is guarantor.

Funding: This work was funded indirectly through programme support by the Wellcome Trust and Medical Research Council. SA is supported by a grant from the Wellcome Trust (No 084538). The Wellcome Trust had no role in the review and in the preparation of this manuscript.

Competing interests: All authors have completed the Unified Competing Interest form at www.icmje.org/coi_disclosure.pdf (available on request from the corresponding author) and declare: no support from any institution for the submitted work; no financial relationships with any institutions that might have an interest in the submitted work in the previous 3 years; no other relationships or activities that could appear to have influenced the submitted work.

Ethical approval: Not required.

Data sharing: No additional data available.

1 Carcillo JA, Tasker RC. Fluid resuscitation of hypovolemic shock: acute medicine's great triumph for children. Intensive Care Med 2006;32:958-61.

2 Mecham N. Early recognition and treatment of shock in the pediatric patient. J Trauma Nurs 2006;13:17-21.

3 Alderson P, Bunn F, Lefebvre C, Li WP, Li L, Roberts I, et al. Human albumin solution for resuscitation and volume expansion in critically ill patients. Cochrane Database Syst Rev 2002;1:CD001208.

4 Alderson P, Bunn F, Lefebvre C, Li WP, Li L, Roberts I, et al. Human albumin solution for resuscitation and volume expansion in critically ill patients. Cochrane Database Syst Rev 2004;4:CD001208.

5 Alderson P, Schierhout G, Roberts I, Bunn F. Colloids versus crystalloids for fluid resuscitation in critically ill patients. Cochrane Database Syst Rev 2000;2:CD000567.

6 Bunn F, Lefebvre C, Li Wan Po A, Li L, Roberts I, Schierhout G. Human albumin solution for resuscitation and volume expansion in critically ill patients. The Albumin Reviewers. Cochrane Database Syst Rev 2000;2:CD001208.

7 Bunn F, Trivedi D, Ashraf S. Colloid solutions for fluid resuscitation. Cochrane Database Syst Rev 2008;1:CD001319.

8 Haynes GR, Navickis RJ, Wilkes MM. Albumin administration-what is the evidence of clinical benefit? A systematic review of randomized controlled trials. Eur J Anaesthesiol 2003;20;10:771-93.

9 Liberati A, Moja L, Moschetti I, Gensini GF, Gusinu R. Human albumin solution for resuscitation and volume expansion in critically ill patients. Intern Emerg Med 2006;1:243-5.

10 Vincent JL, Navickis RJ, Wilkes MM. Morbidity in hospitalized patients receiving human albumin: a meta-analysis of randomized, controlled trials. Crit Care Med 2004;32:2029-38.

11 Wilkes MM, Navickis RJ. Patient survival after human albumin administration. A meta-analysis of randomized, controlled trials. Ann Intern Med 2001;135:149-64.

12 Finfer S, Bellomo R, Boyce N, French J, Myburgh J, Norton R. A comparison of albumin and saline for fluid resuscitation in the intensive care unit. N Engl J Med 2004;350:2247-56.

13 Brierley J, Peters MJ. Distinct hemodynamic patterns of septic shock at presentation to pediatric intensive care. Pediatrics 2008;122:752-9.

14 McKiernan CA, Lieberman SA. Circulatory shock in children: an overview. Pediatr Rev 2005;26:451-60.

15 Carcillo JA, Fields Al, American College of Critical Care Medicine Task Force Committee M. Clinical practice parameters for hemodynamic support of pediatric and neonatal patients in septic shock. Crit Care Med 2002;30:1365-78.

16 Goldstein B, Giroir B, Randolph A. International pediatric sepsis consensus conference: definitions for sepsis and organ dysfunction in pediatrics. Pediatr Crit Care Med 2005;6:2-8. 
17 World Health Organization. Pocket book of hospital care for children: guidelines for the management of common illnesses with limited resources. WHO, 2005.

18 Sparrow A, Hedderley T, Nadel S. Choice of fluid for resuscitation of septic shock. Emerg Med J 2002;19:114-6.

19 World Health Organization. Management of the child with a serious infection or severe malnutrition: guidelines for care at the firstreferral level in developing countries. WHO, 2000.

20 World Health Organization. Emergency triage assessment and treatment (ETAT). Manual for participants. WHO, 2005.

21 Cole RP. The UK albumin debate. Burns 1999;25:565-8.

22 CfRaD. Undertaking systematic reviews of research on effectiveness: CRD's guidance for carrying out or commissioning reviews. 2nd ed. University of York, 2001.

23 Haynes RB, McKibbon KA, Wilczynski NL, Walter SD, Werre SR. Optimal search strategies for retrieving scientifically strong studies of treatment from Medline: analytical survey. BMJ 2005;330:1179.

24 Review Manager (RevMan) [computer programme]. Version 5.0. Nordic Cochrane Centre, Cochrane Collaboration, 2008.

25 Higgins JPT, Green S, eds. Cochrane handbook for systematic reviews of interventions. Version 5.0.2. Cochrane Collaboration, 2008.

26 Alpar EK, Killampalli VV. Effects of hypertonic dextran in hypovolaemic shock: a prospective clinical trial. Injury 2004;35:500-6.

27 Beards SC, Watt T, Edwards JD, Nightingale P, Farragher EB. Comparison of the hemodynamic and oxygen transport responses to modified fluid gelatin and hetastarch in critically ill patients: a prospective, randomized trial. Crit Care Med 1994;22:600-5.

28 Haibach L, Baubeau D, Jahn H. [Significance of a modified gelatin polymer in the control of hypovolemia. Application to hemodialysis] Anesth Analg (Paris) 1976;3:673-89.

29 Ochocka M. [Blood and blood derivatives in the treatment of infants and older children. II]. Pediatr Pol 1984;59:873-80.

30 Pockaj BA, Yang JC, Lotze MT, Lange JR, Spencer WF, Steinberg SM, et al. A prospective randomized trial evaluating colloid versus crystalloid resuscitation in the treatment of the vascular leak syndrome associated with interleukin-2 therapy. J Immunother Emphasis Tumor Immunol 1994;15:22-8.

31 Rackow EC, Falk JL, Fein IA, Siegel JS, Packman MI, Haupt MT, et al. Fluid resuscitation in circulatory shock: a comparison of the cardiorespiratory effects of albumin, hetastarch, and saline solutions in patients with hypovolemic and septic shock. Crit Care Med 1983;11:839-50.

32 Rahman O, Bennish ML, Alam AN, Salam MA. Rapid intravenous rehydration by means of a single polyelectrolyte solution with or without dextrose. J Pediatr 1988;113:654-60.

33 Schortgen F, Lacherade JC, Bruneel F, Cattaneo I, Hemery F, Lemaire $F$, et al. Effects of hydroxyethylstarch and gelatin on renal function in severe sepsis: a multicentre randomised study. Lancet 2001;357:911-6.

34 Tanaka R, Watanabe T. [Effect of lactated ringer solution with 2 percent gelatin on the circulatory and respiratory systems.] Masui 1975;24:873-9.

35 Veneman TF, Oude Nijhuis J, Woittiez AJ. Human albumin and starch administration in critically ill patients: a prospective randomized clinical trial. Wien Klin Wochenschr 2004;116:305-9.

36 Weis KH. [Haemaccel 35: adverse reactions in a multicentric, prospective study.] Anaesthesist 1983;32:488-93.

37 Maitland K, Pamba A, Newton CR, Levin M. Response to volume resuscitation in children with severe malaria. Pediatr Crit Care Med 2003;4:426-31.

38 Maitland K, Pamba A, English M, Peshu N, Marsh K, Newton C, et al. Randomized trial of volume expansion with albumin or saline in children with severe malaria: preliminary evidence of albumin benefit. Clin Infect Dis 2005;40:538-45.

39 Maitland K, Pamba A, English M, Peshu N, Levin M, Marsh K, et al. Pre-transfusion management of children with severe malarial anaemia: a randomised controlled trial of intravascular volume expansion. BrJ Haematol 2005;128:393-400.

40 Akech S, Gwer S, Idro R, Fegan G, Eziefula AC, Newton CR, et al. Volume expansion with albumin compared to gelofusine in children with severe malaria: results of a controlled trial. PLoS Clin Trials 2006;1:e21.

41 Dung NM, Day NP, Tam DT, Loan HT, Chau HT, Minh LN, et al. Fluid replacement in dengue shock syndrome: a randomized, doubleblind comparison of four intravenous-fluid regimens. Clin Infect Dis 1999;29:787-94.

42 Ngo NT, Cao XT, Kneen R, Wills B, Nguyen VM, Nguyen TQ, et al. Acut management of dengue shock syndrome: a randomized doubleblind comparison of 4 intravenous fluid regimens in the first hour. Clin Infect Dis 2001;32:204-13.

43 Wills BA, Nguyen MD, Ha TL, Dong THT, Tran TNT, Le TTM, et al. Comparison of three fluid solutions for resuscitation in dengue shock syndrome. N Engl J Med 2005;353:877-89.

44 Cifra HL, Velasco JNJ. A comparative study of the efficacy of $6 \%$ HaesSteril and Ringer's lactate in the management of dengue shock syndrome 555. Crit Care Shock 2003;6:95-100.

45 Upadhyay M, Singhi S, Murlidharan J, Kaur N, Majumdar S. Randomized evaluation of fluid resuscitation with crystalloid (saline) and colloid (polymer from degraded gelatin in saline) in pediatric septic shock. Indian Pediatr 2005;42:223-31.

46 Roberts JS, Bratton SL. Colloid volume expanders. Problems, pitfalls and possibilities. Drugs 1998;55:621-30.

47 Perel P, Roberts I. Colloids versus crystalloids for fluid resuscitation in critically ill patients. Cochrane Database Syst Rev 2007;4:CD000567.

48 Roberts I, Alderson P, Bunn F, Chinnock P, Ker K, Schierhout G. Colloids versus crystalloids for fluid resuscitation in critically ill patients. Cochrane Database Syst Rev 2004;4:CD000567.

49 Nguyen TH, Nguyen TL, Lei H-Y, Lin Y-S, Le BL, Huang K-J, et al. Volume replacement in infants with dengue hemorrhagic fever/dengue shock syndrome. Am J Trop Med Hyg 2006;74:684-91.

50 Kjaergard LL, Villumsen J, Gluud C. Reported methodologic quality and discrepancies between large and small randomized trials in meta-analyses. Ann Intern Med 2001;135:982-9.

51 Kunz R, Vist G, Oxman AD. Randomisation to protect against selection bias in healthcare trials. Cochrane Database Syst Rev 2007;2:MR000012.

52 Schulz KF, Chalmers I, Hayes RJ, Altman DG. Empirical evidence of bias. Dimensions of methodological quality associated with estimates of treatment effects in controlled trials. JAMA 1995;273:408-12

53 Deeks JJ, Dinnes J, D’Amico R, Sowden AJ, Sakarovitch C, Song F, et al. Evaluating non-randomised intervention studies. Health Technol Assess 2003;7:1-173.

54 Rivers E, Nguyen B, Havstad S, Ressler J, Muzzin A, Knoblich B, et al. Early goal-directed therapy in the treatment of severe sepsis and septic shock. N Engl J Med 2001;345:1368-77.

55 Carcillo JA, Davis AL, Zaritsky A. Role of early fluid resuscitation in pediatric septic shock. JAMA 1991;266:1242-5.

56 Han YY, Carcillo JA, Dragotta MA, Bills DM, Watson RS, Westerman ME, et al. Early reversal of pediatric-neonatal septic shock by community physicians is associated with improved outcome. Pediatrics 2003;112:793-9.

57 Vincent JL. Resuscitation using albumin in critically ill patients: research in patients at high risk of complications is now needed. BMJ 2006;333:1029-30.

58 Wills BA, Oragui EE, Dung NM, Loan HT, Chau NV, Farrar Jl, et al. Size and charge characteristics of the protein leak in dengue shock syndrome. J Infect Dis 2004;190:810-8.

59 Brunkhorst FM, Engel C, Bloos F, Meier-Hellmann A, Ragaller M, Weiler $\mathrm{N}$, et al. Intensive insulin therapy and pentastarch resuscitation in severe sepsis. N Engl J Med 2008;358:125-39.

60 Wiedermann CJ. Systematic review of randomized clinical trials on the use of hydroxyethyl starch for fluid management in sepsis. BMC Emerg Med 2008;8:1.

61 De Jonge $\mathrm{E}$, Levi M. Effects of different plasma substitutes on blood coagulation: a comparative review. Crit Care Med 2001;29:1261-7.

Accepted: 28 June 2010 